\title{
How to know a citizen when you see one? The sex of a citizen
}

\author{
Adriana Zaharijević \\ University of Belgrade, \\ Institute for Philosophy and Social Theory. \\ (adriana.zaharijevic@gmail.com)
}

\begin{abstract}
:
The paper explores how the $19^{\text {th }}$ century scientific discourses naturalized sex. Those highest ranking forms of public knowledge are situated within a broader context of knowledge production on what it is to be human and how the gradation of humanity has been made possible. The paper concentrates on the sexed 'humans' in order to show how sex worked as the political and epistemic tool which foreclosed the domains of citizenship for women. I argue that epistemic incomprehensibility is fundamentally related to the politically liminal or impossible lives. Thus, by using examples from the Victorian sciences, the paper shows how the scientific naturalization of sex actively limited the space of citizenship for women.
\end{abstract}

Key words: women, sex, naturalization, human, citizenship, science, regimes of veridiction.

\section{Internal Boundaries of Citizenship}

The proper history of citizenship begins in the $19^{\text {th }}$ century. According to T. H. Marshall's seminal text which defined citizenship as the principle of equality, ${ }^{1}$ three integral parts of which citizenship consists began to be substantiated or to gain shape during the $19^{\text {th }}$ century. Marshall argued that the civil element, composed of the rights necessary for individual freedom, was established before the Great Reform Act in 1832, the first Act to extend the suffrage. The political element of citizenship refers to the right to participate in the exercise of political power, and the struggle for vote did indeed mark the history of the British $19^{\text {th }}$ century. It ended in 1918, as Marshall stated, when the principle of universal political citizenship had been recognized. Finally, social or social class element, essentially incompatible with the force of industrialization and the laissez-faire state, had to wait for the last decades of the $19^{\text {th }}$ century to be articulated and for the $20^{\text {th }}$ century welfare state to find its, however partial, realization. ${ }^{2}$

Marshall's concept of citizenship is highly contested today and abandoned by many citizenship scholars. And it is so not only because the political and social context from which it emerged endured severe transformation. As Nira Yuval Davis noticed, "society has changed so much that the social prerequisites for citizenship-rationality and solidarity-seem to have disappeared." ${ }^{3}$ Nevertheless, for my purposes here it is still useful because it enables us to identify how this 'principle of equality,' or the "status bestowed on those who are full members of a community" ${ }^{4}$ has been founded on a structural omission. Before the late $19^{\text {th }}$ century, women were not the possessors of civil rights, such as the individual liberty of a person, the right to own property and to conclude valid contracts, to name only a few. ${ }^{5}$ Universal political citizenship of 1918 was not conferred to all individuals universally: English female sex was still partially deprived of it until 1928.

\footnotetext{
1 Marshall, T. H., "Citizenship and Social Class," in Inequality and Society, eds. Jeff Manza and Michael Sauder, (New York: W. W. Norton and Co., 2009 [1950]), 150. Marshall speaks of United Kingdom. In what follows, I will also rely primarily on England as the topological frame of reference, for reasons closely related to the issues of citizenship.

2 Ibid., 148-149.

3 Yuval-Davis, Nira, "The Citizenship Debate: Women, Ethnic Processes and the State," Feminist Review, No. 39, (1991),65.

4 Marshall, "Citizenship and Social Class," 149.

5 Bodichon, Leigh Smith Barbara, A Brief Summary in Plain Language of the Most Important Laws Concerning Women (London: Holyoake and Co., 1854).
} 
How women gained those rights is not subject to my interest here; what were their struggles and what obstacles they encountered in order to be recognized as full and equal members of a community is not what I will investigate. Rather, I will seek to expose what precluded them to be seen as the rightful possessors of rights. This task rests upon two premises. The first one directly confronts with Marshall's notion of citizenship as the principle of equality. Citizenship reveals itself as a principle founded on and operated within a certain set of exclusions. Genealogically speaking, it was constituted as a principle of equality within its own internal boundaries. Those boundaries were populated by people who were deemed undeserving of citizenship and were therefore excluded from the application of the principle itself.

Their exclusion was justified by their different material and symbolic positionality in the civic, political and social space. This leads us to the second premise of this text. The exclusionary character of this principle rested upon understanding of what it meant to be human. Humanity and citizenship became inextricable after the Déclaration des droits de I'homme et du citoyen of 1789 . To be human, to be a man, meant to have certain natural and imprescriptible rights which belonged to an individual only by the dint of his humanity. This was, however, also a basis for his being a full member of a community as the possessor of rights. But to possess rights and to be recognized as their possessor, one had to be the possessor of his own person and to be recognized as a perfectible individual - that is, the person in possession of judgement, self-control, ability for self-creation and knowledge of his own private interests according to which he would act. The discourses surrounding the extension of suffrage to women and working class men throughout the $19^{\text {th }}$ century confirm this assumption. ${ }^{6}$ Thus, parallel to the creation of the discourses about the man and the citizen, other discourses proliferated which created knowledge about those less than human, unequally human and human but not deserving the status of full membership in the community of humans. Those discourses were not mutually exclusive: on the contrary, the notion of a perfectible citizen relied heavily on the existence of those who occupied the boundaries of citizenship, knowable either as inherently imperfectible creatures or as those who might, at certain distant point, deserve this position on the scale of humanity.

In this text, I will re-read some of the nearly forgotten materials which used to constitute knowledge about what was meant to be human or, rather, how some humans became exemplary while others did not. I will concentrate on the sexed 'humans' in order to show how sex worked as a political and epistemic tool which foreclosed the domains of citizenship for women. I will begin with the theoretical groundwork for the historicising of sex. It will be important to show the political investments into the epistemic realm, in order to show that what we know about sex is also, always already, imbibed with the political. In the end, by using the examples from the history of science, I intend to show how 'scientific' knowledge actively participated in the processes which delimited citizenship for and of women.

It needs to be noted that restricting the argument to the domain of scientific public knowledge is not only narrowing the argument, but it also narrows its object. The 'sex' as an entity is an effect of its constitution, articulation and manipulation within the broader space of sexuality which, according to Jeffrey Weeks, unifies discourses, institutions, laws, regulations, policies, scientific theories, medical practices, domesticity, subcultural patterns, and organisation of everyday life. ${ }^{7}$ I will focus on the production of scientific theories - the highest ranking 'public knowledge' - which created the meanings of sex. But these types of meanings should best be seen as entangled with legal dimensions according to which administrative and governmental production of sexuality had been enacted, and with the norms of domesticity upon which everyday life of men and women had been organized.

\section{The construction of sex}

The distinction between gender and sex is a commonplace in feminist literature. Sex is taken to be the natural/material cause or the base of gender which functions as its social/cultural superstructure. Sex is natural, gender is constructed. I want to argue that naturality of sex also belongs to the domain of the superstructure. In other words, natural sex is thinkable, knowable, but also livable, only "within the productive constraints of certain highly gendered regulatory schemas." ${ }^{\prime 8}$ But how can we apply the idea of a construction to something which, so to speak, emanates from the body, which deeply belongs to the materiality of the body? The word 'construction' implies that being sexed, being embodied by a certain sex and being recognized as the possessor of the sex is an effect of the processes of its naturalization. Being situated in a certain sex is a process, and as such it is not devoid of discursiveness: the truth of naturality of sex, its factuality, becomes factual and true within and by means of diverse discourses. To read those discourses genealogically,

\footnotetext{
${ }^{6}$ Zaharijević, Adriana, Osvajanje prava glasa u Engleskoj [The Process of Enfranchisement in England: Becoming a Citizen in the System of Public and Private], PhD dissertation, University of Belgrade - Faculty of Political Sciences, 2013.

7 Viks, Džefri,,,'̌ta je seksualnost?",QT Časopis za kvir teoriju i kulturu, Vol. II, No. 8-9,2011, 243.

8 Butler, Judith, Bodies that Matter. On the Discursive Limits of "Sex" (New York and London: Routledge, 1993), xi.
} 
as Judith Butler says, is to "map out the political parameters of its construction in the mode of ontology." ${ }^{\text {To read them }}$ genealogically is to open up solidified, sedimented spaces that will reveal naturality of the sex as an effect.

Integral to this reading is the search for what Michel Foucault defines as the regimes of veridiction, the changing constellation of rules which condition the emergence of truths. Knowledge operates not only within the regimes of 'truths,' but also with and within the regimes that govern the production of truths. To ascertain what would be describable, one needs to detect the sets of rules which enable "one to establish which statements in a given discourse can be described as true or false." ${ }^{10}$ For that reason, descriptions, seemingly there to impartially depict the nature of a given phenomenon, have a normative dimension as well. Or, taking resort to Butler, whatever is subsumed under the descriptive explanation of gender is always and at the same time prescriptive. The way we think and talk of it is intrinsically related to the question what will be accepted as intelligible or describable as the truth. "Thus, the very description of the field of gender is in no sense prior to, or separable from, the question of its normative operation." ${ }^{\prime 1}$

Here, Butler speaks explicitly of gender. However, early on in her seminal Gender Trouble, she poses a fundamental question on the intelligibility of sex, which would be further elaborated in her later work. "Can we refer," she asks here,

to a 'given' sex or a 'given' gender without first inquiring into how sex and/or gender is given, through what means? And what is 'sex' anyway? Is it natural, anatomical, chromosomal, or hormonal, and how is a feminist critic to assess the scientific discourses which purport to establish such 'facts' for us? Does sex have a history? Does each sex have a different history, or histories? ${ }^{12}$

Why is it more plausible to think of sex as something which belongs to a constellation of natural givens, rather than to conceive of it as a discursive product in which the epistemic and the political merge into each other? What if the very nature of sex, presented as natural and nondiscursive, serves some political and social interests? Butler leaves the question of sex at that proclaiming that the distinction between gender and sex is not a distinction at all, if sex can be proven to be historisible, discursive and thus constructed.

In his Making Sex: Body and Gender from Greeks to Freud published in 1992, Thomas Laqueur writes on the emergence of the factuality of sex, of its history as the history of duality and incommensurability, founding his argument on the thesis that gender in fact preceded sex.

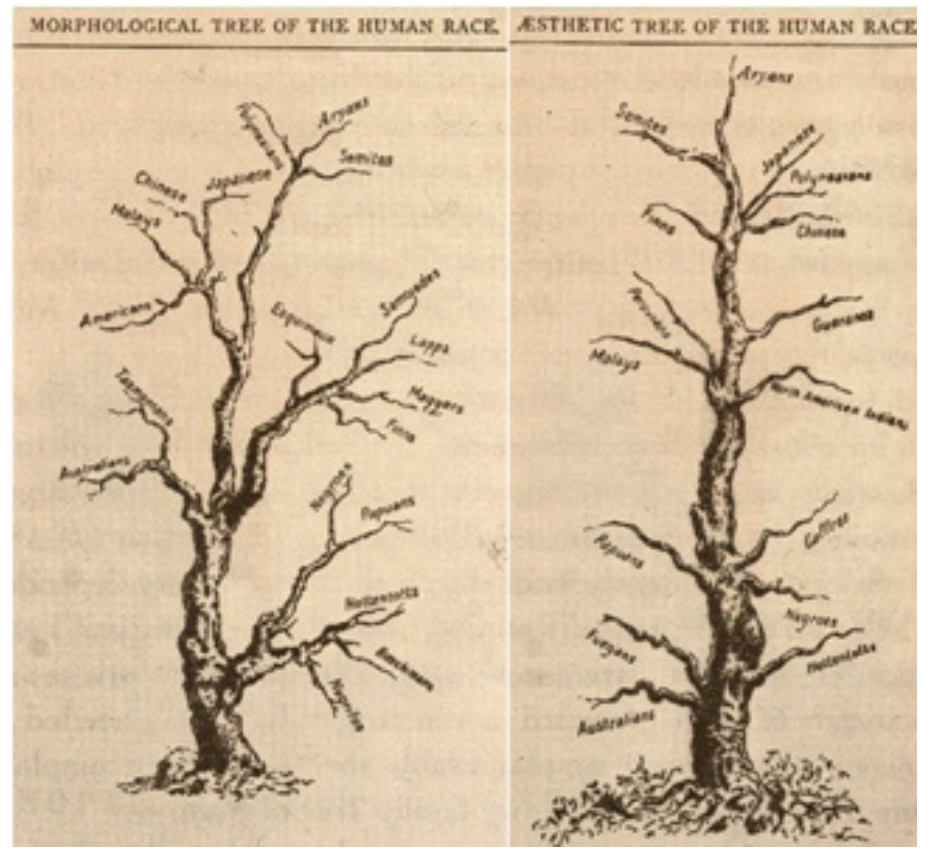

I want to propose instead that in these pre-Enlightenment texts, and even in some later ones, sex, or the body, must be understood as the epiphenomenon, while gender, what we would take to be a cultural category, was primary or 'real.' Gender-man and woman-mattered a great deal and was part of the order of things; sex was conventional, though modern terminology makes such a reordering nonsensical. ${ }^{13}$

Therefore, what Butler states without going into historical elaboration - the claim that one might demonstrate that sex too has a history, which blurs the sex/gender distinction-Laqueur confirms by using historical evidence provided by science.

\footnotetext{
$\overline{9}$ Butler, Judith, Gender Trouble: Feminism and the Subversion of Identity (New York and London: Routledge, 1999), 45.

10 Foucault, Michel, The Birth of Biopolitics, trans. Graham Burchell (New York: Palgrave and MacMillan

2008), 35.

11 Butler, Gender Trouble, xxii.

12 Ibid., 9.

13 Laqueur, Thomas, Making Sex: Body and Gender from Greeks to Freud (Cambridge and London: Harvard University Press, 1992$), 7$.
} 
This theoretical groundwork served to support the counterintuitive thesis that naturality of sex is constructed. Returning to the $19^{\text {th }}$ century, the historical locus of the knowledge production which enabled the making and preserving of the distinction between the natural and the social, factuality and processuality, the discursive and the non-discursive realms, will enable us to see how sex had been constructed as natural. What used to be designated as the sex will in this era become naturalized, or de-gendered, reduced to 'mere nature,' even though it has never been more present in the realm of the civic, political and the social. Naturalization of sex in the $19^{\text {th }}$ century created the insurmountable rift between the natural and the social possible. What it also did was to delineate and determine the capacity for sociability and, in effect, citizenship of those who were defined as the sex.

\section{The regimes of veridiction change}

To substantiate the claim that there was a deep transformation of the epistemological pattern which conditioned the emergence of truths about sex, I will rely on Laqueur's insights laid out in his book Making Sex. Until the late $18^{\text {th }}$ century, male and female bodies were conceived as comparable variants of the same species. This 'one-sex model,' as Laqueur termed it, was founded on the Hellenistic explanation of equilibrium of humoral fluids in relation to which physiological predisposition of a body was defined. It was assumed that cold and wet dominates over healthy female bodies, whereas the balance in male bodies was due to the right proportion of hot and dry humoral elements. Sexual difference between bodies was understood as a difference in degree of a predominant fluid. Prevalence of certain fluids determined the physiological arrangements of bodily parts as well. In this way, female body was a human body which differed from the male only in terms of the degree of its perfection: in Aristotelian tradition, woman was defined as a man, but an imperfect man ('lesser man,' 'homme manqué').

However, by the end of the $18^{\text {th }}$ century radical shift in paradigms occurred and bodies ceased to be seen as universally human. They would now become incomparable, ontologically dual, but complementary. Contrary to the old 'onesex model' which emphasized quantitative difference in degree, the new 'two-sex model' was based on qualitative difference in kind. In order to understand differences between the sexes, it is necessary to divide corporealities as anatomically and physiologically irreducibly different. All of a sudden, incommensurability substituted homologies. ${ }^{14}$

What did instigate such a dramatic shift in understanding of the human? Laqueur is explicit that this fundamental turn was not brought about by the increase and expansion of the existing body of scientific knowledge. "My point here is that new knowledge about sex did not in any way entail the claims about sexual difference made in its name. No discovery or group of discoveries dictated the rise of a two-sex model." ${ }^{15}$ Instead, he shows that certain physiological 'facts', discovered on the eve of the $19^{\text {th }}$ century, confirmed the old Hippocratic suppositions rather than refuting them.

Therefore, contrary to the assumption that anatomy, physiology or biology only find one such basic phenomenon as the human body and then impartially describe it, it turns out that the sheer process of 'finding' a 'given' object has to be seen as belonging to a certain regime of veridiction. What will be found is already absorbed in meanings which determine the course of truthfulness of its explanation. Furthermore, those meanings are not extra-scientific, and their circulation does not belong strictly and exclusively to the field of science. The (scientific) description, taken to be disinterested and objective, is invested with the norms upon which not only representation, but constitution of the new social and political reality depends.

Scientific knowledge is conspicuously present in the formation of the new political and social forms of life. Roughly at the same time when the Declaration of the Rights of Man and of the Citizen was proclaimed, the biological taxonomies adopted Linnaeus's designation of species which tied humans with the rest of the animal kingdom through the feminine mark of Mammalia. At the same time one distinguished humans from the other mammals through the distinctive -masculine-name of Homo sapiens. ${ }^{16}$ Simultaneously, the first female skeleton was reproduced in some anatomy book. "Up to this time there had been one basic structure for the human body, the type of the male."17

Of course, this does not mean that sciences are in some trivial way complicit with the politics in powers, or that science serves them in some obvious and simplistic way. On the contrary, it means that what we know, adopt or produce as knowledge has never been devoid of politicality. The sets of rules which define the potentials for equality, for the application of citizenship as the principle of equality, have always been entangled with our interpretation (scientific or otherwise) of nature, humanity and sex. The gradual appearance of industrial society, the new type of the state, the

${ }_{14}$ Laqueur, Making Sex; see also Bock, Gisela, Frauen in der europäischen Geschichte (München: C. H. Beck, 2000).

15 Ibid., 153.

16 Bourke, Joanna, What it Means to be Human? Reflections from 1791 to the Present (London: Virago, 2011), 6-7.

17 Laqueur, Thomas, "Orgasm, Generation, and the Politics of Reproductive Biology," Representations, No. 14, 1986, 4. 
idea of sovereignty of individuals, free market economy and the novel distribution of social arrangements, colonial dismemberment of the world, and the belief in the possibility for social change (which involved women as well), all of these had their share in the creation of a different set of rules which conditioned the emergence of new truths about the sexed body.

I will not, in what follows, develop arguments in favour or against social change-or, explicitly, women's suffragewhich were also made by some of the scientists whose opinions and theories I will now expound. This is not because I think that those arguments were not relevant in a general struggle for recognition of women's humanity or because I question their significance for the formation of the theories themselves. I want to argue that particular misogynies and 'philogynies' (which were far rarer) contributed less to the process of naturalization of sex than the circulation and embeddness of these narratives in the realm of public knowledge in general. Those authored pieces of knowledge became part of the paradigm, which outlived someone's intimate beliefs. This paradigm still lives with us, impressed on our experiences and on our rational, emotional and bodily reactions to the world. It also still shapes our potentials for equality, even in the time when the old prerequisites for citizenship seem to have disappeared. Those are the knowledges we still struggle not to (ought to) live.

\section{How 'ought' became 'is'?}

Judith Butler claims that bodies are not merely situated within certain discursively determined matrices, but that discourses actually live in the bodies. "They lodge in bodies; bodies in fact carry discourses as part of their own lifeblood." ${ }^{18}$ She speaks here about various discourses that produce codes of intelligibility, intertwined with the codes of political visibility and positionality. Discourses that live within our sexed bodies organize our position on the scale of humanity. They have the power to put our incomprehensible and politically impossible lives "in the shadowy regions of ontology. ${ }^{\prime 19}$ But the regimes of veridiction change, and so does the conception of what constitutes an incomprehensible and politically impossible life. In the $19^{\text {th }}$ century, when entry into citizenship was denied on the basis of sex, the politically impossible life was that of a sexed human.

The examples of 'scientific' discourses which follow, taken from the mid-to late $19^{\text {th }}$ century anthropology, biology, sociology and psychology, should show how the notion of 'natural sex' was formed (and also how it was buttressed by the interrelated notions of race and class). At the time, these sciences at issue were still novel scientific disciplines. Although all of them existed in embryo before the $19^{\text {th }}$ century, they would become constituted as authoritative forms of scientific knowledge during the Victorian era, that is, only after the paradigm shift had already occurred. Amongst them, biology is the only properly 'natural' science, but all of them were characterized by their explicit belief that they primarily dealt with the natural rather than the social phenomena. All of them too, rested on an inherent faith that the natural must be prior to the social.

An example of anthropology makes this clear. Namely, contrary to the early ethnologists who formed a heterogeneous group which tried to read natural history through diversity of languages and cultures, physical anthropologists concentrated on the physical characteristics of the representatives of those 'cultures.' Establishing systematic, coherent and indisputable knowledge about man required enumerating, classifying and categorizing the vital differences between men. Those differences were neither accidental nor incidental; they were not caused by environment or any external random set of circumstances. What caused those differences was detectable-and measurable-in different skeletal structure, hair texture, skin and eye colour, and size of the skull, ${ }^{20}$ and those measurable and essentially disproportionate differences were taken to be the very root of the variety between loosely defined 'cultures.'

James Hunt, the founder of the Anthropological Society of London, which broke away from the existing Ethnological Society of London in 1863 over racial issues, defined anthropology in his "Introductory Address on the Study of Anthropology" as "the science of the whole nature of Man," ${ }^{21}$ the exact and exhaustive science which tackles the natural origin and development of humanity. The exactness and comprehensiveness of anthropology, according to Hunt, is confirmed by its strong links with biology, anatomy, chemistry, natural philosophy and physiology, knowledge that furnishes an anthropologist with necessary materials from which he can deduce the laws regulating the distribution of mankind.

\footnotetext{
18 Meijer, Irene Costera and Baukje Prins, “How Bodies Come to Matter: An Interview with Judith Butler," Signs, Vol. 23, No. 2, $1998,282$.

19 Ibid., 277.

20 Russet, Cynthia Eagle, Sexual Science. The Victorian Construction of Womanhood (Harvard University Press, 1991$), 26$.

${ }^{21}$ Hunt, James, "Introductory Address on the Study of Anthropology, "The Anthropological Review, No. 1, 1863, 2.
} 
The distribution of humanity is understood as the allocation of races, classified according to the definition of the pure racial types inferred not from the arbitrary linkages of cultures but from the irrefutable deductions based on the knowledge of the natural laws. Although this might not be self-evident at first, the very defining process has been organized around one ultimate type which functions as the criterion for the entire comparison. This ultimate type is a white, self-governing, perfectible male individual. Hunt openly opposes the cruel treatment of some types of humans, even though they might have descended from the ape only a few generations ago - if they are now men. But he is also cautious not to be joining in the vulgar error according to which "differences between the Negro and the European might be reduced to the mere complexion issue." When introducing 'psychology' as an equally important sphere of knowledge for the anthropological definition of natural laws of mankind, Hunt insists that the difference "between the European and the African is not so great physically as it is mentally and morally." ${ }^{22}$ His contemporary and like-minded scientist Paul Broca, the president of Parisian Anthropological Society, could have not been more explicit about the way comparison, or rather gradation, between the humans functioned. Comparison between the ideally defined racial types has to take into account the principle of perfectibility, because there is, according to the laws of nature, unequal degree of perfectibility among races. Craniometry, a science made rigorous and respectable by Paul Broca, correlated brain size with intelligence on the assumption of racially unequally applicable principle of perfectibility. Thus he could argue that "never has a people with black skin, woolly hair, and a prognathous face, spontaneously arrived at civilization," ${ }^{23}$ which could also be used to affirm the racial distinction within human species. ${ }^{24}$

Physical anthropology used sciences in order to factualize its underlying belief that "human races could be ranked in a linear scale of mental worth." 25 The pictograms of the 'Family Tree' or the 'Family of Man' visibly witness to that. The older tree imagery comprised several key elements: common roots of all humanity, the uneven development of races shown by the position of the branches, and naturalness of this scheme. By depicting Europeans as the apex (the highest branch), as Anne McClintock argued, the pictogram worked as "an ancient image of a natural genealogy of power," ${ }^{\prime 2}$ and as a persuasive justification of hierarchy in the name of progress. Linearity and progress are even more forcefully displayed in the other pictogram, where anatomy of the human head proves not only our apish ancestry, but also leaves African and other 'lower' races somewhere in-between the first apes and the last Apollo-like white man. The 'Family of Man' is peculiar because it domesticates humanity, turning it into a huge family of those more or less prosperous and blissful creatures, who happened to have been born in different parts of the globe. According to the 'laws of nature,' this made their jaws more or less protruded and their skin more or less dark, and their mental worth more or less pronounced. Domestication notwithstanding, this Family of Man is represented exclusively by men, as if women contributed nothing to this familial progress-or stagnation-of humanity. ${ }^{27}$

The anthropological story of human races would be unfathomable without its companion narrative - that of human sexual(ised) races. Knowledge based on the assumption that races form distinct species corresponded well with the idea of the incommensurability of the sexes. While an insurmountable rift between male and female had been created by the new duality of sexes narrative, race and sex (i.e.non-white race and female sex) became notions which were far more comparable than the divergent and racially indistinct masculinity and femininity, construed by the two-sex model. Race, and more specifically the 'lower' races, has been thus feminized. Females, including white women, were arrested in their development by the comparison with the representatives of the non-white races. Both racialized and sexualized members of humanity have never fully grown to adulthood which came to be inscribed in the anatomicalphysiological-craniological size of their body parts, coupled by their adjunct imperfectability and lesser mental worth.

Both 'civilized women' and 'brutish females' have more often than not constituted a special case, a separate chapter in a treatise, an addendum or have simply been invisible (as in the 'Family of Man' pictogram). However, they are vital for the scientific explanation of the natural distribution of mankind. As the race itself, which is defined so as not to provide space for haphazardness and irregularity, the sex is also formed as static and immutable. It is firmly positioned on the scale of perfectibility and mental worth, where it had a dual role. It was used in correlation with race, in order to underline essential comparability between female sex and non-white races. This correlation served to feminize nonwhite races, and to racialize female sex. On the other hand, it was also used to emphasize the essential incomparability between the two sexes, or rather the whole female sex and the invisible sex of the white man.

22 Hunt, "Introductory Address," 3.

23 Quoted in Russet, vSexual Science, 27.

24 Bronfman, Alejandra, Measures of equality: social science, citizenship and race in Cuba, 1902-1940, (University of North Carolina Press, 2004), 30.

25 Gould, Stephan Jay, The Mismeasure of Man(London and New York: W.W. Norton and Company, 1981$), 118$.

${ }_{26}$ McClintock, Anne, Imperial Leather: Race, Gender and Sexuality in the Colonial Context (New York: Routledge,1995), 37.

27 Ibid., 39. 
Let us give a few examples. Women were constructed as humans incapable of maturity, and thus physically and mentally analogous to the civilized (white) child and 'uncivilized' (non-white) adult man. German anthropologist, Emil Huschke wrote in 1854 that the "Negro brain possesses a spinal cord of the type found in children and women, and beyond this, approaches the type of brain found in higher apes." 28 Civilization and skin colour notwithstanding, women are placed in a natural position which makes them sexually incomparable to the man of the same race. In his elaboration of the laws of the variations of brain volume and their relation to intelligence, Gustave Le Bon pointed to a seemingly strange fact of a race whose male subjects (Parisians) occupy the most elevated rank by the volume of their brain, while their female counterparts occupy the disgraceful rank of the females of the "inferior races, who are obliged to share in the work of man."29 (It should come as no surprise that in the midst of mathematical estimates and anthropometrical measurements, this piece of knowledge performs the function of forewarning to those who would advocate equal rights of women and men.) Women of different races differ less amongst themselves in terms of their mental worth then men do, which, according to Le Bon, make all women comparable not to men but to gorillas, savages and children. ${ }^{30}$ Thus, although civilization processes put (white) man on the top the human ladder, as an apogee of evolutionary progress, women, be they white or non-white, share a position of immaturity as the sex. Famous Italian criminologist and physician, Cesare Lombroso, confirms this by saying that "in general, according to all authorities, and in all races, but more so in civilized ones, the female skull is more childlike in capacity and shape than the masculine, and it is always inferior and always offers less variation than that of the male."31

The degree of civilization of a certain race is established, according to Lombroso and Ferrero, by the difference between the male and female skull, measured intra-racially and in comparison to other racial types. Naturalized racial differences-or, within discourses of physical anthropology, differences explained by the natural laws-relate 'civilized' women to 'inferior' races, thus supporting the naturalization of females into humans that, regardless of their degree of civilization, lag behind in perfectibility. "Geometry of the body," as McClintock persuasively stated, had "mapped the psyche of the race," ${ }^{32}$ but it was also used for the mapping of the 'psyche' of all women, almost turning them into a distinct species.

Here anthropology-the science of the whole nature of Man-required more than anatomy. In this vein, Paul Broca insisted on broader definition of inferiority of female sex:

We might ask if the small size of the female brain depends exclusively upon the small size of her body. Tiedemann [German anatomist] has proposed this explanation. But we must not forget that women are, on the average, a little less intelligent than men, a difference which we should not exaggerate but which is, none the less, real. We are therefore permitted to suppose that the relatively small size of the female brain depends in part upon her physical inferiority and in part upon her intellectual inferiority. ${ }^{33}$

And Paul Topinard, Broca's chief disciple, explained sexually differential intelligence in 1888 with different evolutionary histories which, although they tend to portray our very distant ancestors, in fact replicate Victorian middle-class humanity:

The man who fights for two or more in the struggle for existence, who has all the responsibility and the cares of tomorrow, who is constantly active in combatting the environment and human rivals, needs more brain than the woman whom he must protect and nourish, than the sedentary woman, lacking any interior occupations, whose role is to raise children, love, and be passive. ${ }^{34}$

Although positively against the idea that the races of men form distinct species, ${ }^{35}$ Charles Darwin seemed to have agreed with both Broca's and Topinard's account on women. In his The Descent of Man, after many a hundred of pages

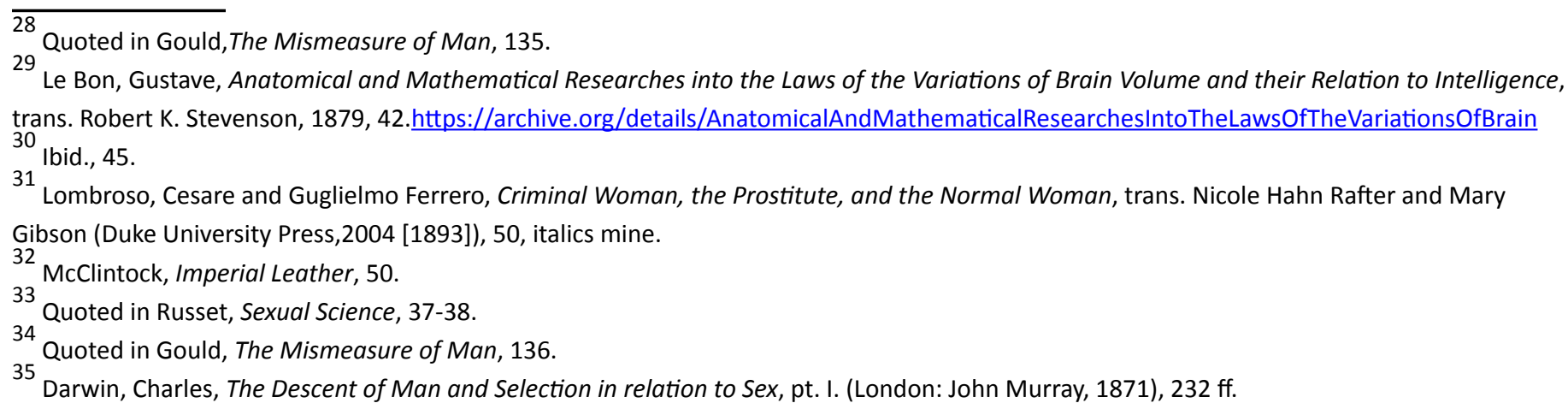


on sexual selection of insects, fish, birds and mammals, Darwin finally arrives at sexual character of Man. There Darwin states that apart from being considerably taller, heavier and stronger than woman, the male is also more courageous, pugnacious and energetic, and has a more inventive genius. The woman is rounder, broader, and less hairy. She also matures earlier, but remains more similar to children throughout her adult life than men do. This might be related to the "formation of her skull [which] is said to be intermediate between the child and the man." ${ }^{36}$ The said size of the skull generates differences in intellectual power, and this is perhapswhy man attains to a higher eminence in whatever he takes up than woman can attain. ${ }^{37}$ Let us note that Darwin is, unlike many other Victorian scientists, very scrupulous in his statements. He also claimed that "males differed much more from each other than did the females. This fact indicates that, as far as these characters are concerned, it is the male which has been chiefly modified, since the races diverged from their common and primeval source." ${ }^{38}$

The last statement which places women low because of their biologically explained atavism is also very much in accordance with Darwin's chief argument about the sexual selection, which links the combat of the males and the choice of the female. While he did admit a considerable role in sexual selection to the females of the lower animals, Darwin denied significance to the human females in the same process. Projecting the conventions of Victorian sexuality into nature by "casting animal sexuality in the terminology of courtship, marriage and spousal fidelity" ${ }^{39}$ has been accompanied by socializing human female's nature. Namely, Darwin spoke of the boldest and strongest men in a barbarous condition who, according to the law of the battle and to the principle of natural selection, succeeded in general struggle for life. Ancestry also mattered and "there can be little doubt that the greater size and strength of man, in comparison with woman, together with ... his greater courage and pugnacity, are all due in chief part to inheritance from some early male progenitor, who like the existing anthropoid apes, was thus characterized." ${ }^{40}$ Finally, men acquired higher intellectual and moral characteristics through the processes of sexual selection, because they needed to be prudent to dispose of their rivals over the female. The case of women has been fundamentally different. Since they are mainly nurturing creatures, they are denied agency, and by consequence the prerogative of the choice. Separate spheres, and the consequent positioning of women in the protected/covered domain, were harmonized with the conception of the lack of variation in women, or their general passivity and non-assertiveness.

The centrality of human male choice, allegedly natural in kind, in fact mirrored the prevalent social standards of Darwin's own era. Or, as Jim Endersby noticed, "the evidence of Victorian society seemed to him to demonstrate that men had largely seized the power of choice." ${ }^{\prime 1}$ Men, or rather human males, are thus triply advantageous: by ancestry, by variation and by being better equipped for the struggle in life. Human females, whose active role in either natural or sexual selection has been diminished, if not taken away altogether, have left with only one advantage - their passive beauty.

However, Darwin's investigation into how and why there are differences between the races does not rely only on the assumption of an intrinsic distinction between the sexes. Standards of Victorian sexuality, smuggled into his explanation of human nature, relayed equally on a prevalent understanding of sex and class. Middle-class domestic ideology which recognized assertive and vigorous men in the public arena, and coy women who were well kept in the bourgeois fortress of home, came to have a prominent place in Darwin's explanation of human female agency. In civilized races, where there is no longer need for the crude struggle for life, men retained the role of the worker for mutual subsistence. Although Darwin affirms that "women in all barbarous nations are compelled to work at least as hard as the men," ${ }^{42}$ which is what make those nations barbarous still, he would simply exempt numerous women of his own nation from the very definition of the female sex - because they also worked. Thus not only did Darwin's natural history depend on the Victorian maxim 'incommensurable, but complementary,' but it also entailed class prescriptive definition of what sex is.

Like Darwin, Herbert Spencer also believed that exemption of women from labour should be seen as the touchstone of high civilization. ${ }^{43}$ This is somewhat baffling when one reads the first line of his elaboration of the rights of women, as

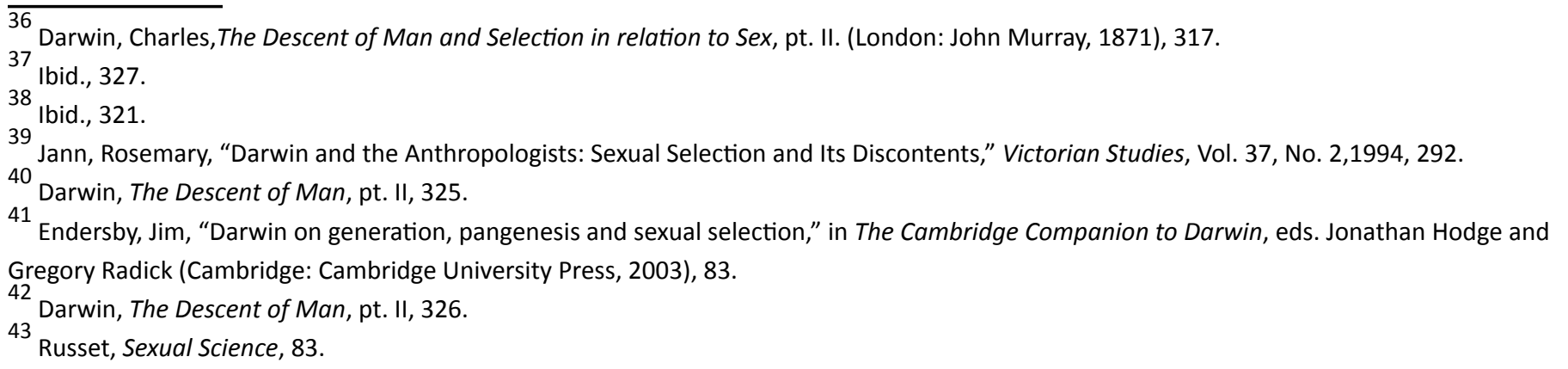


early as in 1851, according to which "equity knows no difference in sex." ${ }^{\text {"4 }}$ Only two decades later and two years after the publication of The Descent of Man, Spencer would venture to demonstrate that there are fundamental differences between the sexes. Those differences are psychological, i. e. natural, and as such, they are crucial for understanding how society functions. Spencer thus asks, "Are the mental natures of men and women the same?" only to give his answer right away. "That men and women are mentally alike is as untrue as that they are alike bodily." 45

One distinctive mental trait which Spencer recognized as adjusted to the welfare of the race refers to women's fascination with power of any kind. Although this brings back woman's choice into the discussion, it will not expand female agency in any way. Spencer argued that since the cessation of marriage by capture or by purchase, feminine choice played an important part. Women who were fascinated by power, bodily or mental-and increasingly, social-

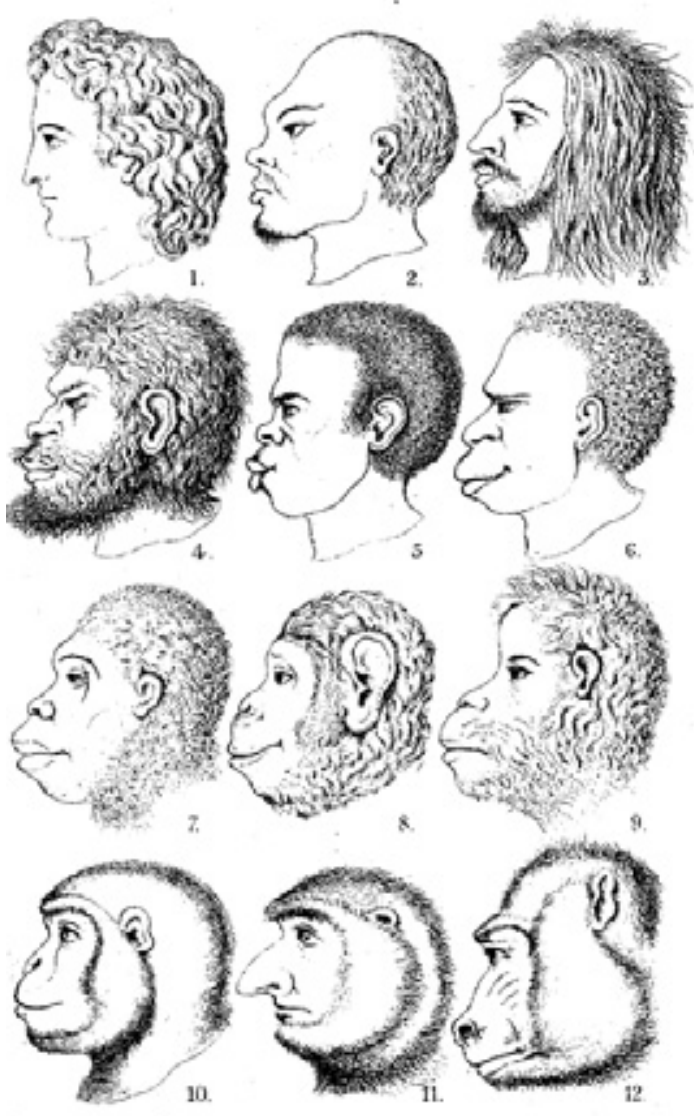

Die Familiengruppe der Kalarrhinen (siehe Seite 555 ). "and who married men able to protect them and their children, were more likely to survive in posterity than women to whom weaker men were pleasing, and whose children were both less efficiently guarded and less capable of self-preservation if they reached maturity." ${ }^{\prime 6}$ With Spencer, love of power, especially social power which is the only one which can be really promising in terms of efficient guardianship, becomes naturalized as the mental trait of the female sex. This should come as no surprise, because Spencer viewed men and women as primarily determined by their adaptation to the paternal and maternal duties. $^{47}$

This adaptation, so vital for the functioning of society, is physiological in kind. It is also responsible for the other qualitative sexual difference derived from the specific procreative features of the female body. Although it matures earlier than the male body, the evolution of the female also ends earlier and it is something "necessitated by the reservation of vital power to meet the cost of reproduction." ${ }^{48}$ Arrested development, substituted by the constant possibility of giving birth, is explained by 'the physiological truth' that women, especially when able to give birth, exhale smaller quantities of carbonic acid than men, which is the main cause of underdevelopment of their neuromuscular system, and therefore underdevelopment of limbs and the brain that moves them. Physiological processes which prepare the female body to become maternal, hastening at first its psycho-somatic development, will then arrest it when it becomes capable for reproduction. And this is why women, by the laws of nature, can never arrive to the latest products of human evolution - "the power of abstract reasoning and the most abstract of the emotions, the sentiment of justice." ${ }^{\prime 9}$

There is only a step from here to George Romanes, the forgotten Darwinian psychologist whose text "Mental Differences of Men and Women" was widely read by the Victorian 'general public.' Referring to The Descent of Man, Romanes will develop what Darwin merely hinted at when he introduced mental sexual differences. According to Romanes, they are so colossal that "in the animal kingdom as a whole the males admit of being classified, as it were, in one psychological species and the females in another." ${ }^{\prime \prime 0}$ As the title of his text suggests, Romanes did not dare to further this thesis by taking into account the whole animal kingdom, but limited himself to the part of that kingdom wherein this difference is by far the most prominent. Founding his 'psychological' explanation on the truths confirmed by physiology, biology and anthropology, Romanes proclaimed women to be "losers in the intellectual race as regards acquisition, origination

\footnotetext{
${ }^{44}$ Spencer, Herbert, Social Statics: or, The Conditions essential to Happiness specified, and the First of them Developed (London: John Chapman, 1851), chap. XVI. http://oll.libertyfund.org/title/273/6292 on 2013-11-19

45 Spencer, Herbert, "Psychology of the Sexes," Popular Science Monthly, Vol 4. 1873, 30-31.http://en.wikisource.org/wiki/Popular Science Monthly/Volume 4/November 1873 /Psychology of the Sexes

46 Ibid., 35.

47 Ibid., 31.

48 Ibid., 32.

49 Ibid.

50 Romanes, John George, “Mental Difference of Men and Women," Popular Science Monthly, Vol. 31, 1887, 382.
} 
and judgement." ${ }^{\prime 51}$ All the characteristics deemed to be necessary for the process of self-creation, all of them resolutely related to the perfectibility of an individual, are missing in women, because the average brain-weight of women is about five ounces less than that of man. ${ }^{52}$

However, although it is psychologically permanently incapacitated in certain domains of humanity, 'female species' is by nature better equipped in some other areas of human excellence. Those qualities "wherein the female mind stands pre-eminent are affection, sympathy, devotion, self-denial, modesty; long-suffering, or patience under pain, disappointment, and adversity; reverence, veneration, religious feeling, and general morality." ${ }^{\prime 3}$ Nature has given women pre-eminence in 'general morality' but it has, as Spencer argued, left her out from the distribution of the sentiment of justice.

\section{The impossible sex of a citizen}

In the $19^{\text {th }}$ century scientific discourse, nature was established as the key explanatory frame of what it is to be human. This was the time when it was finally resolved that "the male is defined by his humanity; the woman by her sexuality," Joanna Bourke ${ }^{54}$ says. With the help of science, men and women became two almost irreducible and incomparable human species, severed by what was to become their natural sexual difference. This coincided with the production of equivalence between 'Man' and 'citizen.' Women, as sexed humans, were hence rightfully positioned within the boundaries of humanity, but without the limits of citizenship. Their being sexed precluded them to be seen as the rightful possessors of rights - either imprescriptible rights which by nature belonged to (male) humans (of the civilised races and classes) or civic, political and social rights pertaining to citizenship.

However, the politicality of the vague and pliable term 'nature,' which was so easily used to justify unequal application of the principle of equality, is glaringly present in the highest ranking domain of public knowledge. "The long-established customs of their country" have placed in the hands of women of England "the high and holy duty of cherishing and protecting the minor morals of life, from whence springs all that is elevated in purpose, and glorious in action." 55 These words might have belonged to George Romanes who described women's natural supremacy in general morality, denying them the same in the sphere of judgement. Or they might have belonged to Spencer who domesticated woman's body, mind and will; or to Darwin who described the whole female sex as lacking in variation, because its sphere was defined by cherishing what was being protected for them by the species that acts according to the law of the battle.' However, the author of those words was a woman, Sarah Stickney Ellis. She has been long forgotten, although quite famous and widely read in her own time, mostly by women. She was not a scientist, but a mere writer of manuals on female domestic virtues and books about women's role in society. Ellis' early Victorian beliefs in the supremacy of the English middle rank and in the naturalness of the separate social spheres, in the holiness of the woman's domestic duty as her main duty within the general social, civic and political space, became integral part of the scientific explanations of the naturality of sex.

\section{Bibliography:}

Bock, Gisela. Frauen in der europäischen Geschichte. München: C. H. Beck, 2000.

Bodichon, Leigh Smith Barbara. A Brief Summary in Plain Language of the Most Important Laws Concerning Women. London: Holyoake and Co., 1854.

Bourke, Joanna. What it Means to be Human? Reflections from 1791 to the Present. London: Virago, 2011.

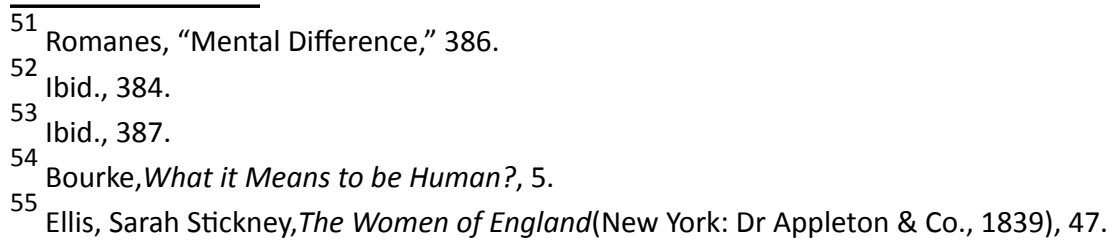


Bronfman, Alejandra. Measures of equality: social science, citizenship and race in Cuba, 1902-1940. University of North Carolina Press, 2004.

Butler, Judith. Bodies that Matter.On the Discursive Limits of "Sex". New York and London: Routledge, 1993.

Butler, Judith. Gender Trouble: Feminism and the Subversion of Identity. New York and London: Routledge, 1999.

Darwin, Charles. The Descent of Man and Selection in relation to Sex, pt. I. London: John Murray, 1871.

Darwin, Charles. The Descent of Man and Selection in relation to Sex, pt. II. London: John Murray, 1871.

Ellis, Sarah Stickney. The Women of England. New York: Dr Appleton \& Co., 1839.

Endersby, Jim. "Darwin on generation, pangenesis and sexual selection." In The Cambridge Companion to Darwin, edited by Jonathan Hodge and Gregory Radick, 69-91. Cambridge: Cambridge University Press, 2003.

Foucault, Michel. The Birth of Biopolitics, trans. Graham Burchell. New York: Palgrave and MacMillan, 2008.

Gould, Stephan Jay. The Mismeasure of Man. London and New York: W.W. Norton and Company, 1981.

Hunt, James. "Introductory Address on the Study of Anthropology." The Anthropological Review No. 1 (1863): 1-21.

Jann, Rosemary. "Darwin and the Anthropologists: Sexual Selection and Its Discontents." Victorian Studies Vol. 37 , No. 2 (1994): 287-306.

Laqueur, Thomas. "Orgasm, Generation, and the Politics of Reproductive Biology." Representations No. 14 (1986): $1-41$.

Laqueur, Thomas. Making Sex: Body and Gender from Greeks to Freud. Cambridge and London: Harvard University Press, 1992.

Le Bon, Gustave. Anatomical and Mathematical Researches into the Laws of the Variations of Brain Volume and their Relation to Intelligence, trans. Robert K. Stevenson. 1879. Last modified November 27, 2013 https://archive.org/ details/AnatomicalAndMathematicalResearchesIntoTheLawsOfTheVariationsOfBrain

Lombroso, Cesare and Guglielmo Ferrero. Criminal Woman, the Prostitute, and the Normal Woman, trans. Nicole Hahn Rafter and Mary Gibson. Duke University Press, 2004 [1893].

Marshall, T. H. "Citizenship and Social Class." In Inequality and Society, edited by Jeff Manza and Michael Sauder, 148154. New York: W. W. Norton and Co., 2009 [1950].

McClintock, Anne. Imperial Leather: Race, Gender and Sexuality in the Colonial Context. New York: Routledge, 1995.

Meijer, Irene Costera and Baukje Prins. "How Bodies Come to Matter: An Interview with Judith Butler." Signs, Vol. 23, No. 2 (1998): 275-286.

Romanes, John George. “Mental Difference of Men and Women.” Popular Science Monthly, Vol. 31 (1887): 383-401.

Russet, Cynthia Eagle. Sexual Science. The Victorian Construction of Womanhood. Harvard University Press, 1991.

Spencer, Herbert. Social Statics: or, The Conditions essential to Happiness specified, and the First of them Developed. London: John Chapman, 1851. Last modified November 27, 2013 http://oll.libertyfund.org/title/273/6292 on 2013$\underline{11-19}$

Spencer, Herbert. "Psychology of the Sexes." Popular Science Monthly, Vol 4 (1873). Last modified November 27, 2013 http://en.wikisource.org/wiki/Popular Science Monthly/Volume 4/November 1873/Psychology of the Sexes 
Viks, Džefri. „Šta je seksualnost?“ QT Časopis za kvir teoriju i kulturu, Vol. II, No. 8-9 (2011): 239-249.

Yuval-Davis, Nira. "The Citizenship Debate: Women, Ethnic Processes and the State." Feminist Review, No. 39 (1991): 58-68.

Zaharijević, Adriana. Osvajanje prava glasa u Engleskoj [The Process of Enfranchisement in England: Becoming a Citizen in the System of Public and Private]. PhD dissertation, University of Belgrade - Faculty of Political Sciences, 2013. 